\title{
Viscoelastic Property of Yield Stress Fluids under Wall-Slip and Simple Method of Wall-Slip Suppression
}

\author{
Yasunori Sato ${ }^{*}$, Masashi Kolzumi ${ }^{* *}$, Yukinobu SuginarA ${ }^{* *}$, and Tsutomu TaKahashi ${ }^{* *}$, \\ * Department of Science of Technology Innovation, Nagaoka University of Technology \\ 1608-1 Kamitomioka, Nagaoka, Niigata 940-2188, Japan \\ ${ }^{* *}$ Department of Mechanical Engineering, Nagaoka University of Technology \\ 1608-1 Kamitomioka, Nagaoka, Niigata 940-2188, Japan
}

\begin{abstract}
A large part of surreys, pastes and thick emulsions exhibit as a yield stress fluid and they sometimes show a wall-slip that forms a low-viscous shear layer near the wall surface. The occupation of the wall-slip makes lower the apparent viscosity and induces misunderstanding about the rheological property of the test sample. The wall-slip appears easier on the lower roughness of the wall. We measure the stress-strain-shear rate relations of a yield stress fluid using the parallel plate flow cells, which have a different roughness, and examine the viscous and elastic contributions on the strain. In order to evaluate the viscous and elastic contribution of the strain, the one-mode Maxwell model fitting is applied to the stressstrain relationship below the yield stress point. The strain induced by the viscosity is strongly affected by the roughness of the plate and the apparent viscosity in the smooth plate decreases below 1/10 to the rough plate's viscosity. To avoid the wall-slip effect to the viscosity without making the plate rough, we propose that a small number of spherical particles disperse the test fluid to block the flow at the vicinity of the wall. The dispersing particles do not change the elasticity, but the viscosity can be improved up to the rough plate's value.
\end{abstract}

Key Words: Yield stress fluid / Wall-slip / Maxwell model / Stress-ramp test / $\alpha$-gels

\section{降伏応力流体の粘弾性特性に及ぼす壁面滑りの効果と簡易抑制方法の検討}

\author{
佐藤＼cjkstart靖徳", 小泉 理志**, 杉原 幸信"*, 高橋 勉 ${ }^{* *,+}$
}

(原稿受理：2020 年 6 月 25 日)

\section{1. 緒 言}

1922 年にビンガムが “Fluidity and plasticity”で定義したビ ンガム流体 ${ }^{1)}$ は, ある臨界值を超えない限り応力が作用して も形状を保持するが，臨界值を越えた瞬間に流動を開始する. この臨界值を降伏応力といい, 流動を開始する瞬間の挙動を 「降伏」という。 ビンガム流体は降伏を示す流体の最も単純 なモデルであり, 現実の物質は降伏前後に非常に複雑な挙動 を示す． 降伏挙動を示す流体を総称して「降伏応力流体」と よび, 近年, 解析的にも実験的にも研究が活発に進められて いる ${ }^{2)}$. 金属材料の降伏と異なり降伏応力流体では降伏が発 生しても静置することで再度降伏挙動を示す程度まで力学特 性が回復する ${ }^{3)}$. また, 実在の降伏応力流体ではビンガム流 体のように降伏応力以下でも僅かに流動し, このときの流動 は強い時間依存性を有する ${ }^{4}$. さらに, 一部の流体では降伏

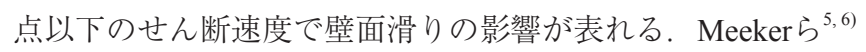
は変形可能な粒子 $(d=220 \mathrm{~nm})$ を含むミクロゲルの滑り挙

\footnotetext{
$\dagger$ 長岡技術科学大学 大学院 工学研究科 機械創造工学専攻

T940-2188 新潟県長岡市上富岡町1603-1

E-mail : ttaka@nagaokaut.ac.jp, Tel : 0258-47-1611-(9728)
}

動を包括的に報告している．彼らは表面が粗いプレートと表 面が平滑なプレートを用いてレオロジー測定および流路内部 の速度分布計測を行った。平滑なプレートでは分散粒子の変 形に起因した壁面近傍で生じる潤滑層によって滑りが発生し, 降伏直前の領域におけるレオロジー特性に影響を及ぼすと報 告している。名畑ら ${ }^{7-9)}$ は, 降伏応力を有するクリーム状の サンプルおよび高濃度分散系のサンプルに対して回転型レオ メータによるレオロジー測定を実施し, 流路の表面粗さが測 定結果に影響を及ぼすことを報告した。すなわち，表面が平 滑な通常の流路では定常粘弾性試験において応力のステップ 的な増加が生じ不連続な結果が得られるのに対し, サンドブ ラスト処理を施し表面を粗くした流路では連続的な挙動が得 られることを示した。これは降伏点以下の低せん断速度域に おいて, 流路表面近傍に低粘度で高せん断速度の薄い層が形 成されたことが原因であると, 名畑らは考察している。この 薄い層が形成されたことによって見かけ上滑っているように 見えるため, 壁面滑りと呼ばれる。壁面滑りについてもさま ざまな報告がなされており，滑り層の厚さは $1 \mathrm{~nm} \sim 1.6 \mu \mathrm{m}$ 程度であることが報告されている, 6, 10-14). これら先行研究の 詳しい内容は, 2.1 節に記載する。また, Coussotら ${ }^{15)}$ は, 降 伏応力流体では降伏後に試料の一部が始めに大きく流動し, 
速度分布の不均一性であるシアバンドが形成されることを報 告している。佐藤ら ${ }^{16)}$ は, 平行円板型流路の上下円板に作 用するトルクをそれぞれ同時に検知することができる Twindrive 型レオメータによる応力増加試験において降伏応力前 後で上下円板間に応力の差が生じることを報告した。これは せん断応力が時間的に増加する過渡的な流れ場において壁面 滑りが発生することで，瞬間的にせん断応力の連続性が崩れ ることを示している，同時に，上下円板で同じ応力が作用す ると仮定してレオロジー特性を評価している従来の測定では 降伏応力流体の特性が正しく理解できないことを示した，壁 面滑りの発生の瞬間を定量的に求めた報告は他にはほとんど なく, また, 壁面滑りの抑制については壁面粗さ以外の方法 は提案されていない. 降伏の発生と壁面滑りの関係や滑りの 発生前後におけるレオロジー特性の変化についての詳細な検 討が急がれる.

これらの状況を鑑み, 本研究では降伏応力流体において （1）壁面滑り発生時の粘弾性特性を詳細に把握すること, お よび（2）流路の表面粗さに起因する降伏直前の壁面滑りを 制御するための基礎的な知見を得ることを目的とする。目的 （1）について，マイクロオーダーの表面粗さを有する金属製 流路とナノオーダーの表面粗さを有するガラス製流路を用い, 滑り発生の効果があらわれやすい応力増加試験を適用して流 路の表面粗さが流動特性に及ぼす影響を明らかにする。さら に壁面滑りの影響が強く表れる降伏応力以下の挙動に対して, 発生するひずみの弾性と粘性による寄与分を単一緩和マクス ウェルモデルによる近似から推定し, 壁面滑りとの関係を検 討する. 目的（2）の壁面滑りの発生を簡易的に抑制する方 法として, 滑り面のせん断層厚さよりも十分に大きな球状粒 子を試料に少量分散する方法を試みる，粒子添加による壁面 滑りの抑制の可否について, 単一緩和マクスウェルモデル近 似により推定される粘性的挙動によるひずみの大きさをもと に検討する。これにより, サンドブラスト処理などを施した 特殊な流路を用いるのではなく, 試料に大きな影響を及ぼさ ない程度のわずかな粒子の添加によって壁面滑りを簡易的に 抑制し, 試料のレオロジー特性を評価する手法の確立に向け た基礎的知見を得る。

\section{2. 実験装置，方法および試料}

\section{1 使用試料}

本研究では, イオン交換水を分散媒, 流動パラフィンを分

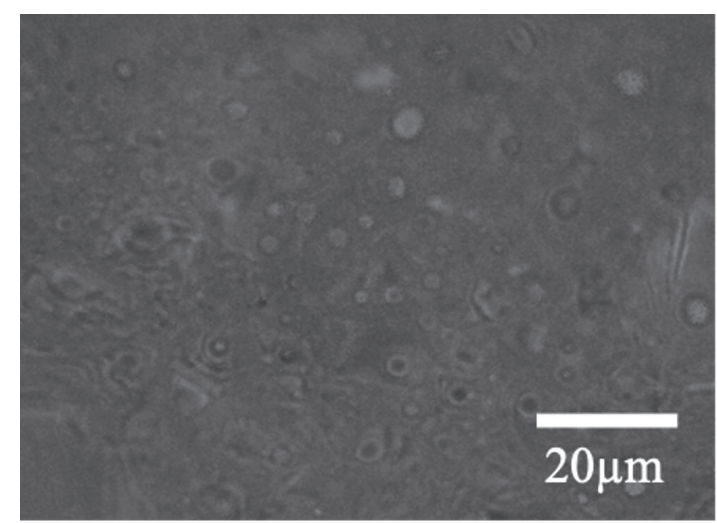

Fig. 1 Optical microscope image of $\alpha$-gel O/W emulsion. The average diameter of droplets is about $4 \mu \mathrm{m}$.
散質とし，乳化粒子間に $\alpha$ ゲルによるゲルネットワークが 形成された $\alpha$ ゲル $\mathrm{O} / \mathrm{W}$ エマルション ${ }^{17)}$ を降伏応力流体の典 型的な挙動を示す試料の一つとして選定した， $\alpha$ ゲルは高級 アルコールと界面活性剤が相互作用によって会合し，ラメラ 液晶構造に近い形態をとっており，化粧品業界では製品の流 動特性の調整を目的に添加されている ${ }^{9)}$. 本研究で用いる $\alpha$ ゲル O/W エマルションの生成には, ベヘニルアルコールと アニオン系の界面活性剤であるステアロイルメチルタウリン ナトリウム $(\mathrm{SMT})$, 水の3 成分系による $\alpha$ ゲルを用いた。 Fig. 1 に光学顕微鏡で撮影した試料の画像を示す。画像全体 で確認できる白い部分は乳化粒子であり，粒径は $3 \sim 5 \mu \mathrm{m}$ 程度である。また，乳化粒子の周りに見える灰色の部分に $\alpha$ ゲルのネットワークが形成されており乳化を安定させている.

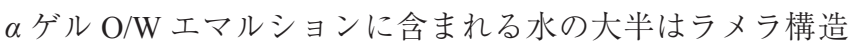
の層間に保持されており，この系では最大およそ $85 \%$ の水 をラメラ構造間に保持できることが報告されている ${ }^{17)}$. また， 本研究におけるレオロジー測定は最長 2 時間以上の測定時間 になるが，その間試料は乾燥しないため実験結果に乾燥の影 響は含まれていないことが予備実験から明らかになっている。

壁面滑りの抑制を目的に球状粒子を上記の $\alpha$ ゲル O/W エ マルションに分散させる。球状粒子には，Microbead 社の表 面未処理のポリエチレン製粒子を使用した。粒子径の効果を 確認するため, 直径 $d$ がそろった $d=10,20,40,80 \mu \mathrm{m}$ の 粒子を用意した。Table I に示すように壁面滑りの厚さは $1 \mathrm{~nm} \sim 1.6 \mu \mathrm{m}$ 程度 ${ }^{5,6,10-14)}$ である。 なお, 本研究ではすでに 形成された滑り面を止めるのではなく，滑り面の形成に至る 微小な亀裂の進展を阻止することに着目する。著者らは，金 属の塑性変形の前段階で発生する転位や亀裂の進展のように, エマルションにおいても滑り面の発生前に液滴数個程度の微 小な範囲での亀裂が各所で発生してそれらが成長し，合一し て滑り面となると予想している。そこで, 亀裂の発生を防ぐ 効果や亀裂が進展しようとした際に垂直な壁に阻まれて止ま る効果を期待し, エマルションの液滴の 2 倍から 20 倍の直 径を持つ粒子を混入させた。

それぞれの球状粒子が分散されている $\alpha$ ゲル O/W エマル ションを光学顕微鏡で撮影した画像を Fig. 2 に示す. 球状粒 子の分散がレオロジー特性に及ぼす影響を低く抑えるため粒 子濃度を 5 wt.\%とした。 $\alpha$ ゲル $\mathrm{O} / \mathrm{W}$ エマルションに粒子を 混入して 5 分間以上匙で擋拌した後, 非接触式のホモジナイ ザーによってさらに 3 分間撹汼した。各種測定は粒子を分散 させてから 1 日以上静置させた試料により実施した。なお， 2 週間程度放置しても分散粒子が沈降しないことを確認して いる。

Table I Summary of previous reports about slip phenomena in different systems.

\begin{tabular}{|c|c|c|c|}
\hline Study & System & Particle radius & Slip layer thickness \\
\hline Aral and Kalyon (1994) & $\begin{array}{l}\text { Glass spheres in polymer } \\
\text { binder }(\Phi=0.63)\end{array}$ & $\sim 50 \mu \mathrm{m}$ & $1.6 \mu \mathrm{m}$ \\
\hline Buscall et al. (1993) & $\begin{array}{l}\text { Stabilized latex particles in } \\
\text { organic solvent }+ \\
\text { nonadsorbing polymer }\end{array}$ & $160 \mathrm{~nm}$ & $\begin{array}{c}2 \mu \mathrm{m} \rightarrow 3 \mathrm{~nm} \\
(\Phi \sim 0.2 \rightarrow 0.55)\end{array}$ \\
\hline Princen (1985) & $\begin{array}{l}\text { Concentrated silicone oil in } \\
\text { water emulsions }\end{array}$ & $\approx 9 \mu \mathrm{m}$ & $\approx 20 \mathrm{~nm}$ \\
\hline Russell and Grant (2000) & $\begin{array}{l}\text { Silica particles }+ \text { grafted } \\
\text { poly(butylmethacrylate) in } \\
\text { a poor solvent }\end{array}$ & $\approx 70 \mu \mathrm{m}$ & $<1 \mathrm{~nm}$ \\
\hline Salmon et al. (2003) & $\begin{array}{l}\text { Monodisperse silicone oil } \\
\text { in water/glycerol emulsion } \\
\qquad(\Phi=0.75)\end{array}$ & $\approx 1 \mu \mathrm{m}$ & $10 \mathrm{~nm} \rightarrow 90 \mathrm{~nm}$ \\
\hline Steven (2004) & Microgel pastes & $220 \mathrm{~nm}$ & $\approx 2-10 \mathrm{~nm}$ \\
\hline
\end{tabular}




\section{(a) $10 \mu \mathrm{m} 5 \mathrm{wt} . \%$}

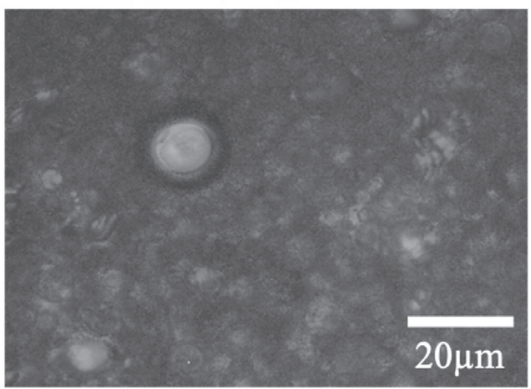

(b) $20 \mu \mathrm{m} \_5 w t . \%$

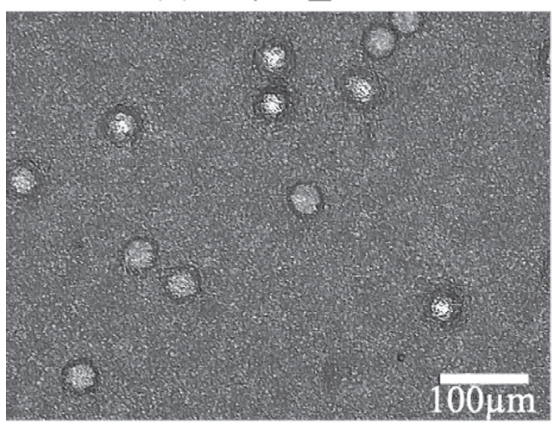

(c) $40 \mu \mathrm{m} 5 \mathrm{wt} . \%$

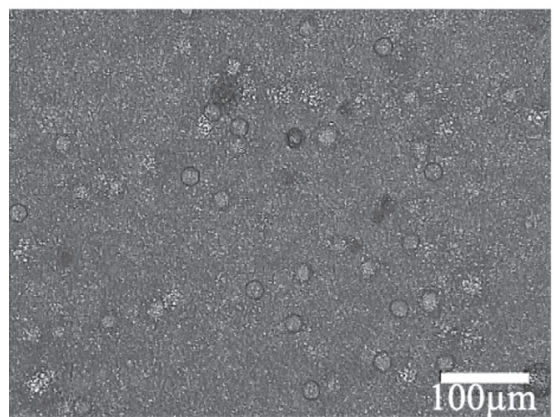

(d) $80 \mu \mathrm{m} \_5 w t . \%$

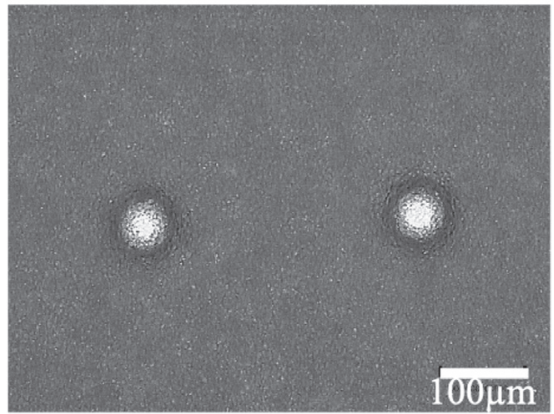

Fig. 2 Optical microscope image of $\alpha$-gel $\mathrm{O} / \mathrm{W}$ emulsion dispersed spherical particles with different diameter $(d=10 \mu \mathrm{m}, 20 \mu \mathrm{m}, 40 \mu \mathrm{m}, 80 \mu \mathrm{m})$.

\section{2 レオメータおよび使用した流路}

実験には応力制御型ツインドライブレオメータ MCR702 (Anton Paar 社) を使用した。本装置は流路を設置する軸の 上下それぞれに駆動モーターおよびトルク・トランスデュー サーが装備されており，上下流路の回転を自由に制御しなが ら同時にトルクを測定できる。本研究では上部円板を固定さ せながら下部円板のみを回転させる「2EC 分離トランス デューサーモード」に設定した。使用した流路は, 下部の回 転側として直径 $25 \mathrm{~mm}$ の金属製円板, 直径 $43 \mathrm{~mm}$ のガラス
製円板の二種類を用い，上部の非回転側は直径 $25 \mathrm{~mm} の$ 金 属製円板を使用した。ステンレス流路は，流路表面の凹凸の 和である最大高さ粗さ $\mathrm{Rz}$ が $1.6 \mu \mathrm{m}$ である。 ガラス流路は, 流路表面の最高点と最低点の高低差である面精度が $31.6 \mathrm{~nm}$

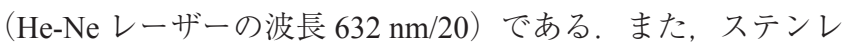
ス流路とガラス流路の表面はどちらも親水性である.

\section{3 応力増加試験}

本研究では降伏挙動を観察するために応力増加試験を用い る ${ }^{18)}$. 応力増加試験はせん断応力をゼロから所定の值（最大 印加応力）まで一定の割合（応力増加率 $a \mathrm{~Pa} / \mathrm{s}$ が一定）で増 加させる試験であり，降伏的な挙動を持つ流体に対しては， 試料が大変形し始める臨界のせん断応力とひずみ，すなわち 降伏応力と降伏ひずみを評価できる点で有効である。また， 応力を徐々に増加させることで, 壁面滑りが影響するせん断 速度領域から全く影響を及ぼさないせん断速度領域まで一度 の試験で判断することが可能である。試料ローディングの影 響を排除するためにプレシアとして応力増加試験（応力増加 率 $0.5 \mathrm{~Pa} / \mathrm{s}$, 最大印加応力 $100 \mathrm{~Pa}$ ）の流動を与え, 所定時間

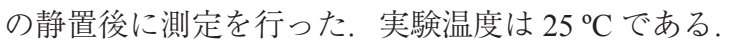

\section{4 応力ひずみ線図に対する単一緩和マクスウェルモデル 近似}

一般的な降伏応力流体の降伏応力以下の力学的特性は弾性 的性質が支配的であるが粘性的性質も併せ持つ。本研究では 応力増加試験で得られた降伏応力以下の挙動に対して単一緩 和マクスウェルモデルによる近似を行い，見かけの弾性率 $E$, 粘性係数 $\eta$ を算出する。 以下に，実験により得られたひずみ とせん断応力の時間的関係から単一緩和マクスウェルモデル でフィッティングを行う際の近似式を導出する。単一緩和マ クスウェルモデルを単純せん断流動に適用すると式(1)とな る.

$$
\tau+\lambda \frac{d \tau}{d t}=\eta \frac{d \gamma}{d t}
$$

ここで, 緩和時間 $\lambda$ は, 弾性率と粘性係数との比であり, 式 (2)で表される.

$$
\lambda=\frac{\eta}{E}
$$

また, 応力増加試験におけるせん断応力は $\tau=a t$ で定義され る. 初期条件として $t=0 \mathrm{~s}$ のき $\gamma=0$ を考慮すると, ひず み $\gamma$ の過渡的挙動は式(3)のように得られる。

$$
\gamma=\frac{a}{\eta}\left(\frac{1}{2} t^{2}+\frac{\eta}{E} t\right)
$$

最小二乗法を用いて式(3)が実験結果に最も一致するように 見かけの弾性率 $E$, 粘性係数 $\eta$ を算出する。 ここで, 弾性力 によって発生する弾性ひずみ $\gamma_{E}$ および粘性力によって発生 する粘性ひずみ $\gamma_{\eta}$ は，それぞれ式(4)および式(5)で表される.

$$
\begin{aligned}
& \gamma_{E}=\frac{a}{E} t \\
& \gamma_{\eta}=\frac{a}{2 \eta} t^{2}
\end{aligned}
$$




\section{3. 実験結果および考察}

\section{1 壁面滑りが降伏点以下の流動特性に影響するせん断流 動条件の検討}

Ann ${ }^{19)}$ は，ある応力において壁面滑りが発生している条 件では滑りなし条件よりも大きなひずみを示すと報告してい る.このため一定のせん断応力下では滑り面の形成段階で加 速が生じ, せん断層を伴う速度分布が十分発達して平衡状態 に達すると定常流になるという非定常な現象が発生する ${ }^{20)}$. 本研究で使用する応力増加試験では一定の割合でせん断応力 を増加し続けることにより壁面滑りの発生による急な流れ場 の変化を抑制し，比較的に連続的な挙動を観察することが可 能となる. 応力増加試験では応力増加率が流れ場を決める重 要な因子である。そこで, 表面粗さが大きく異なるガラス製 流路と金属製流路により得られる挙動の差異と応力増加率の 関係について検討する。

Fig. 3 に応力増加率を $0.01,0.05,0.1,0.5 \mathrm{~Pa} / \mathrm{s}$ に設定した応 力増加試験の結果を示す. 流路隙間は $0.5 \mathrm{~mm}$, 最大印加応 力は $100 \mathrm{~Pa}$ である. Fig. 3 に示すすべての結果において応力 ひずみ線図には 2 つ不連続な点, すなわち, 低ひずみ領域 の第 1 降伏点と高ひずみ領域の第 2 降伏点が明確に確認され る。第 1 降伏点が一般的に降伏応力流体を特徵づける重要な 挙動であるが，第 2 降伏点を有する試料は他にも多く実在す る. Fig. 3(a) に示す応力増加率が最も低い条件である $0.01 \mathrm{~Pa} / \mathrm{s}$ においては, 第 1 降伏前の低せん断応力域でのひず みはどちらの流路においてもごくわずかであるが, 第 1 降伏 点に近い領域でガラス製流路において壁面滑りに起因すると 思われる不連続なひずみの増加が観察された。 また, Fig. 3 (b) と (c) に示す応力増加率 $0.05 \mathrm{~Pa} / \mathrm{s}$ および $0.1 \mathrm{~Pa} / \mathrm{s}$ の条件で は, 第 1 降伏発生後の領域では流路による差がほとんど見ら れないが，第 1 降伏発生前の低ひずみ領域において金属製流 路の結果が極めて低いひずみ領域から緩やかに変化するのに 対し, ガラス製流路では傾きの急な挙動を示した.さらに, $\tau=0.1 \mathrm{~Pa}$ において生じるひずみは金属製流路で $\gamma=1 \times 10^{-4}$ 程度の值を示し, ガラス製流路では $\gamma=6 \times 10^{-4}$ 程度の值で ある。これは同じ時間でガラス製流路は金属製流路の約 6 倍 移動していることを意味し, 壁面近傍の滑りが発生した証拠 と考えられる，応力増加率 $0.5 \mathrm{~Pa} / \mathrm{s}$ の Fig. 3(d) を見ると, 金 属製流路とガラス製流路の流動曲線は一致しており, 流路の 表面粗さは計測された流動特性に対して影響を及ぼさないと いえる. また, 第 1 降伏点以下の低ひずみ領域では直線的な 変化を示す。以上のことから, 流路の壁面滑りに及ぼす流路 表面粗さの影響は非常にゆっくりとした加速せん断流動場で ある第 1 降伏前の領域において顕著に現れることが明らかと なった。

なお, 流路の濡れ性に関して, Bonnら ${ }^{21)}$ は単純な $\mathrm{O} / \mathrm{W} 工$ マルションに対して濡れ性が異なる2つのガラス流路（親水 性 / 疎水性）を用いて測定すると, 疎水性のガラスでは壁面 滑りが抑制され, 親水性ガラスでは壁面滑りが発生したと報 告している。 しかし, 本研究で用いたステンレス流路とガラ ス流路はどちらも親水性であること， $\alpha$ ゲル $\mathrm{O} / \mathrm{W}$ エル ションはBonnらが対象としたエマルションよりも複雑な系 であり流路表面における親疎水性の効果は弱まること, さら に疎水性ガラスと親水性ガラスで測定した結果に有意な差が

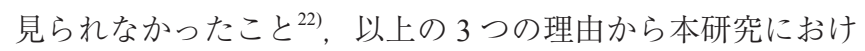

(a) $a=0.01 \mathrm{~Pa} / \mathrm{s}$

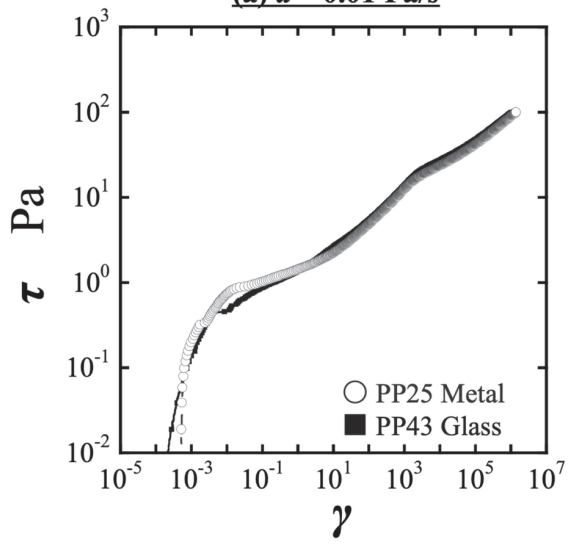

(b) $a=0.05 \mathrm{~Pa} / \mathrm{s}$

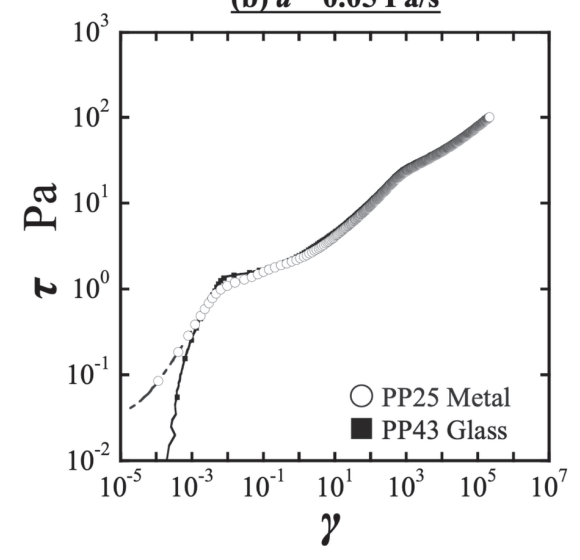

(c) $a=0.1 \mathrm{~Pa} / \mathrm{s}$

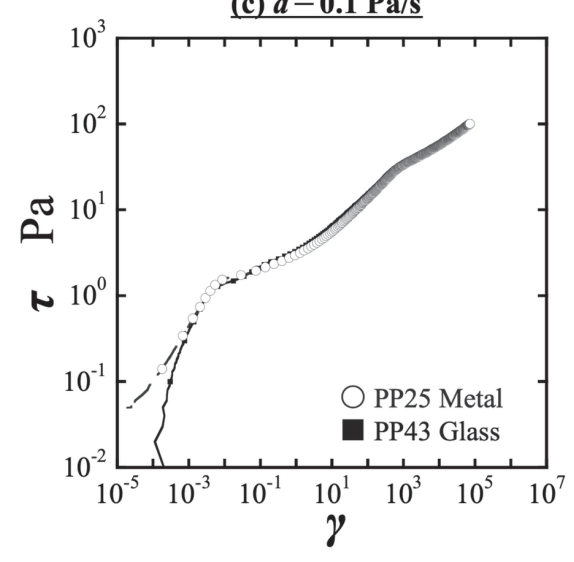

(d) $a=0.5 \mathrm{~Pa} / \mathrm{s}$

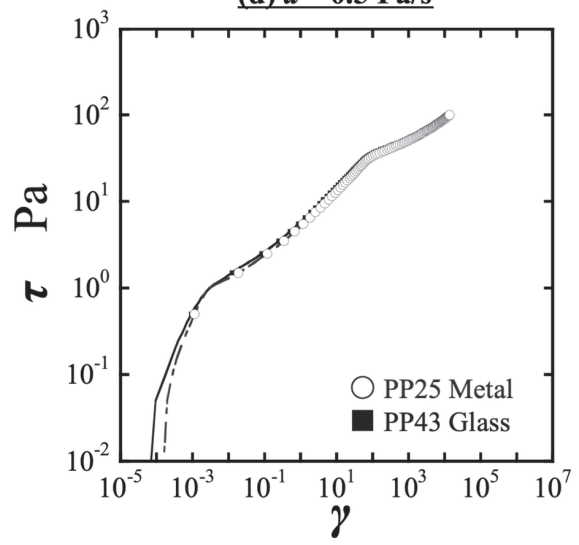

Fig. 3 Effect of surface roughness in stress-strain curve with different stressramp rates. The strain behavior has a difference between the rough plate (Metal) and the smooth plate (Glass) in the low stress, especially the low stress-ramp rate. 
る測定結果は流路の濡れ性よりも表面粗さによる影響が強い と考えられる.

壁面滑りによるせん断層では弾性的性質は希薄になり粘性 流動が支配的であると考えられる。そこで, Andreasら ${ }^{23)} の$ 応力ひずみ線図に対する領域分けを適用し，第 1 降伏点以下 の微小ひずみ領域を弾性と粘性の観点から検討する. Andreasら ${ }^{23)}$ は, 応力とひずみの関係が線形に増加している 領域が弾性的な振る舞いを示す固体領域，傾きが変化したと ころから降伏点までが弾性と粘性の両方の振る舞いを示す固 液領域，降伏点以上が粘性的な振り舞いを示す液体領域であ ると提案している. Fig. 4 に第一降伏前の流動領域を拡大し, 上記の領域分けを適用した応力増加率 $0.05 \mathrm{~Pa} / \mathrm{s}$ および $0.5 \mathrm{~Pa} / \mathrm{s}$ の結果を示す. Fig. 4(a)を見ると, 応力増加率 $0.05 \mathrm{~Pa} / \mathrm{s}$ の金 属製流路では試料は降伏が発生する直前までのほとんどの領 域で弾性的な振る舞いをしているのに対して，ガラス製流路 では流動直後のおよそ $\gamma=7.5 \times 10^{-4}$ において弾性と粘性の どちらも影響する固液領域に遷移していることがわかる。ま た，金属製およびガラス製流路における固体領域ではひずみ 量に差が生じており，ガラス製流路では壁面滑りが生じたと 考えられる。 これに対し, 応力増加率 $0.5 \mathrm{~Pa} / \mathrm{s}$ とした Fig. 4 （b）を見ると，固体領域における2つの流路の結果は表面粗 さにかかわらずよく一致している。応力増加率を大きくする と, ガラス製流路においても試料がただちに流路表面から連 続的に変形し, 滑り面の形成によるスティック・スリップが発
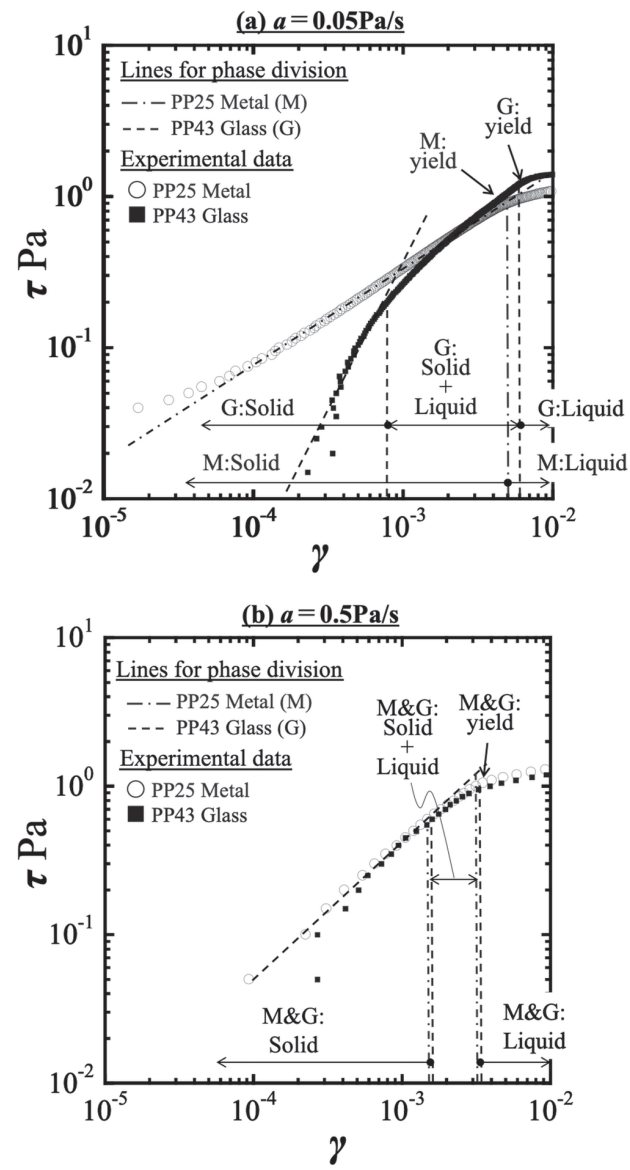

Fig. 4 Transition from solid-state to liquid-state in stress-strain curve measured by stress-ramp rate $a=0.05 \mathrm{~Pa} / \mathrm{s}$ and $a=0.5 \mathrm{~Pa} / \mathrm{s}$. The behavior under the yield point in the solid-state and solid-liquid state is influenced by the stress-ramp rate.
生しなかったと推測される。本結果のように応力増加率よっ て第 1 降伏点以下の流動特性が変化したことは, 滑り面の形 成にとって変形速度の関数となる粘性が無視できないことを 示唆する.つまり, Andreasら ${ }^{23)}$ の方法によって固体として 定義した領域にも粘性の影響は含まれており，壁面滑りが発 生する降伏点以下の領域のひずみを定量的に評価するために は弾性と粘性の両方を考慮する必要があることがわかった。

\section{2 壁面滑りが粘弾性特性に及ぼす影響の定量的評価}

壁面滑りは測定対象の粘度を見かけ上低下させることを考 慮すると, 応力ひずみ曲線の各瞬間のひずみを構成する弾性 により生じたひずみと粘性により生じたひずみの割合を知る ことは重要である。そこで，弾性物性值（弾性率 $E$ ) と粘性 物性值（粘度 $\eta ）$ をとつずつ有する粘弾性モデルである単 一緩和マクスウェルモデルにより実験結果を近似し，その結 果をもとに各瞬間のひずみにおける弾性と粘性の効果を分離 して考察することを試みる. 降伏応力以下の挙動に注目する ことから, 最大印加応力は第 1 降伏応力より低い $0.5 \mathrm{~Pa}$ に設 定した．流路隙間は $0.5 \mathrm{~mm}$ である. Fig. 5 およびFig. 6 に応 力増加率 $0.05 \mathrm{~Pa} / \mathrm{s}$ と $0.5 \mathrm{~Pa} / \mathrm{s}$ におけるひずみの時間変化をそ れぞれ示す。まず, これらの結果を応力増加試験における単 一緩和マクスウェルモデルのひずみの過渡的変化を表す式

(a) PP25 Metal

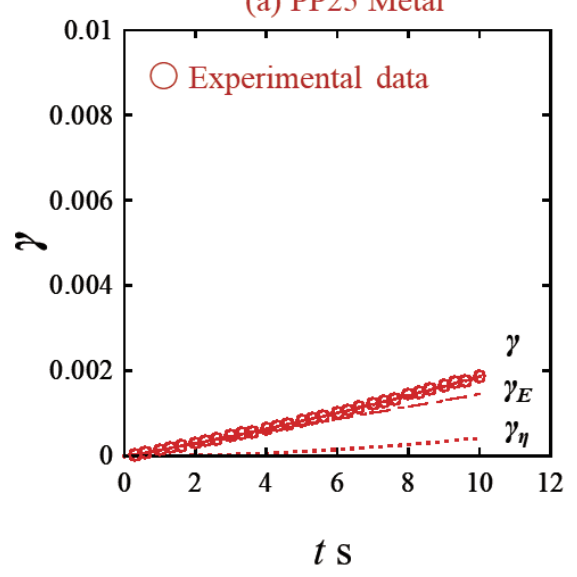

(b) PP43 Glass

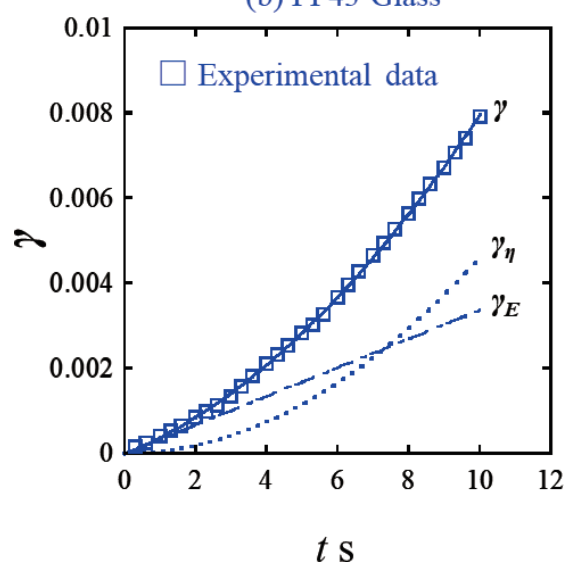

Fig. 5 Strain behavior over test time in $a=0.05 \mathrm{~Pa} / \mathrm{s}$, elastic strain $\gamma_{E}$ and viscous strain $\gamma_{\eta}$ obtained by one-mode Maxwell model fitting. (a) The strain in the metal plate increases linearly and the elastic strain is dominating in whole the test. (b) The strain in the glass plate increases like a quadratic function, which means that the viscous strain is generated by the wall-slip. 
(3)で近似し（図中の実線），それぞれの挙動に対応する見か けの $E$ とを算出した。そして, これらの結果を式(4)と （5）に代入し，ひずみの弾性による成分と粘性による成分を 求めた。

$a=0.05 \mathrm{~Pa} / \mathrm{s}$ の結果を示す Fig. 5 を見ると, ステンレス流 路ではひずみが直線的に増加しているのに対し, ガラス製流 路では二次曲線的に増加していることがわかる。最終的に到 達するひずみ量は, ガラス製流路がステンレス流路の約 4 倍 となる。ささら，ステンレス流路では発生するひずみのほと んどが弾性によるひずみであることがわかる。, 一方，ガラス

(a) Experimental data

(Same vertical axis range to Fig.5)

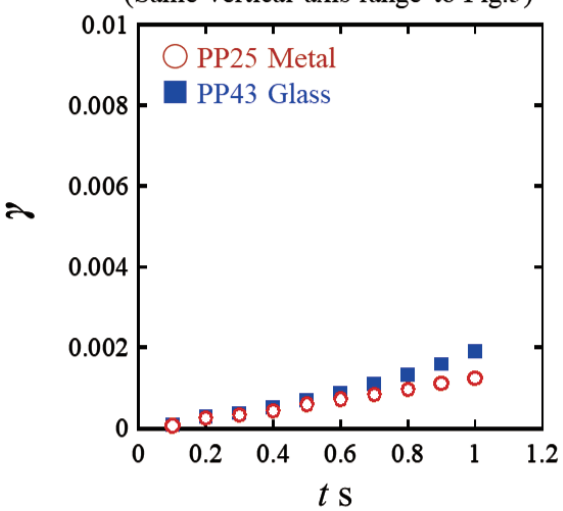

(b) PP25 Metal

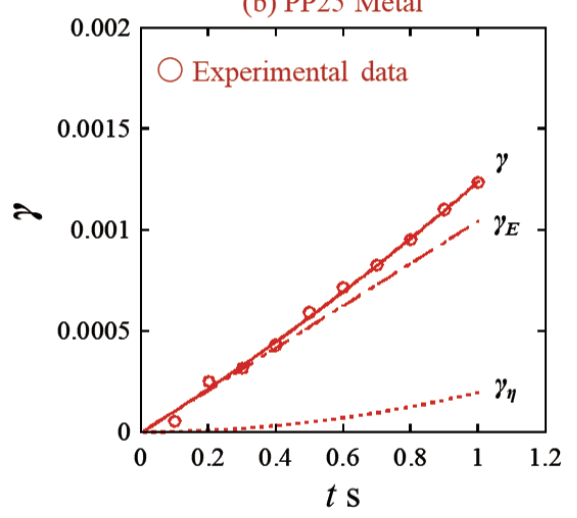

(c) PP43 Glass

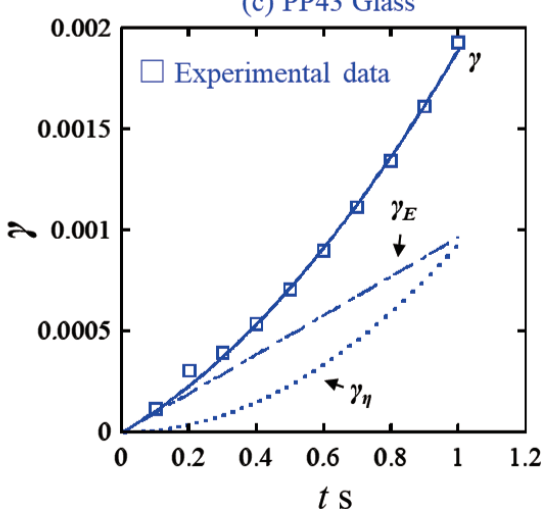

Fig. 6 Strain behavior over test time (the stress increases) in $a=0.5 \mathrm{~Pa} / \mathrm{s}$, elastic strain $\gamma_{E}$ and viscous strain $\gamma_{\eta}$ obtained by one-mode Maxwell model fitting. (a) Compering to the Fig. 5 in the same vertical axis range, both strains in the metal plate and the glass plate seem to increase linearly. (b) The strain in the metal plate increase linearly and the elastic strain is dominant, which is independent of the stress-ramp rate. (c) The strain behavior in the glass plate is close to quadratic function and the viscous strain is the almost same value at the end of the test.
製流路では粘性によるひずみが大きく，ある時刻以降は弾性 ひずみを上回ることが読み取れる。

$a=0.5 \mathrm{~Pa} / \mathrm{s}$ の結果を示す Fig. 6 (a) を見ると, 2 つの流路の 結果はほぼ重なっているように見える。しかし, Fig. 6(b)と (c) の解析結果を見ると, ガラス製流路では粘性によるひずみの 割合が大きく，明確に金属製流路とは異なることがわかる.

Fig. 7 は単一緩和マクスウェルモデル近似により得られた 見かけの $E$ と $\eta$ に対する応力増加率 $a$ の影響を示している 金属製流路とガラス製流路の結果を比較すると，弾性率 $E$ は流路によって大きな差は生じず，特に応力増加率 $a$ が大き い場合はよく一致する。一方，粘度 $\eta$ はガラス製の結果が金 属製に対して一桁程度小さく，その減少率も異なる。これは ガラス製流路表面で生じた壁面滑りによるひずみの二次曲線 的な増加によって，見かけ上粘度が小さく評価されたと考え られる。以上から, 測定に用いる流路の表面粗さが壁面滑り を引き起こし，試料の粘性の評価に影響を及ぼすことがわ かった

\section{3 粒子分散された試料における定常粘弾性試験}

流路の表面粗さが粘性の評価に影響を与えることはレオロ ジー測定としては好ましくない。壁面滑りの影響を排除し, 試料本来のレオロジー挙動を把握するためには, 名畑ら の提案によるサンドブラスト処理をした流路を使うことが 1 つの方法である。しかし，可視化やレオ・オプティック測定 のためにガラスを流路として使用したい場合や，特殊加工し た流路を別途用意することが難しい場合などもあり，流路表 面の状態に依存せず試料本来の挙動を容易に把握することが 出来れば便利である。そこで，壁面滑りの発生を制御し表面 粗さの影響を低減する簡便な方法として，壁面滑りによるせ ん断層の厚さよりも遥かに大きい球状粒子を分散させる方法 を提案する

まず球状粒子を分散させた試料に対して定常粘弾性試験を

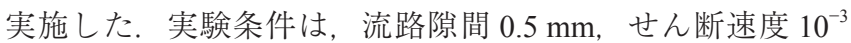
$\sim 10^{3} \mathrm{~s}^{-1}$ の範囲である。また測定治具は直径 $25 \mathrm{~mm} の$ 金属 製平行円板流路を用いた. Fig. 8 に定常粘弾性試験から得ら れた粘度曲線を示す。 $\alpha$ ゲル $\mathrm{O} / \mathrm{W}$ エマルションだけの条件 と粒子を分散した条件の粘度はほぼ一致している。低せん断 速度領域を拡大すると粒子なし条件と $d=80 \mu \mathrm{m}$ が最も高い 粘度を示し $, d=10,20,40 \mu \mathrm{m}$ の順番で低い粘度を示して いる，次に高せん断速度領域の粘度曲線に注目すると，粒子

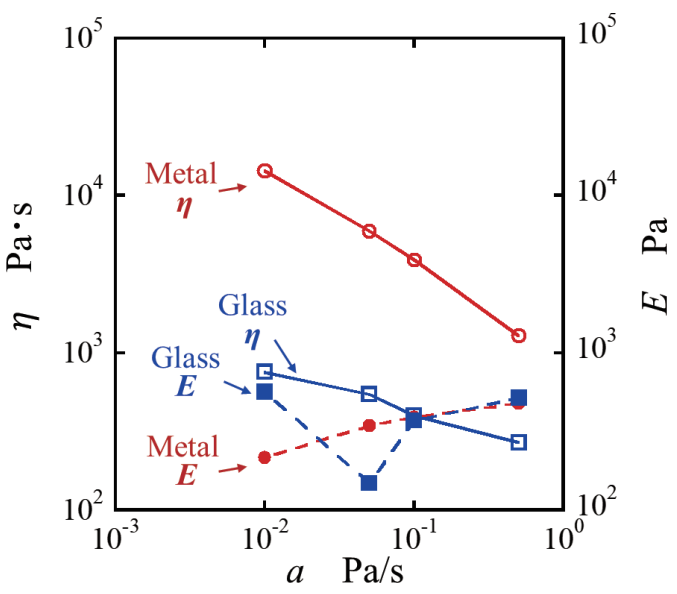

Fig. 7 Stress-ramp rate dependence of viscoelastic property in both plates. Each slope depends on the plate's roughness. 


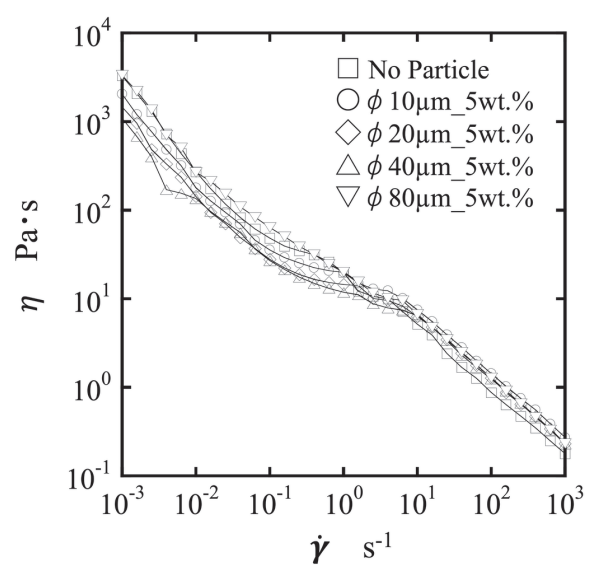

Fig. 8 Flow-curve in each sample dispersing the sphere particle of different diameters. All condition of the particle size is almost good agreement in the entire shear rate. The strain in the lowest shear rate already exceeds the 1 st yield point.

なし条件だけわずかに低い粘度を示すが，その他の条件はほ ぼ同じ程度の粘度であることがわかる，以上のように，球状 粒子を試料に分散させることでサンプルの定常粘度がわずか に変化することを考慮して, 今後の議論を進める。

\section{4 分散粒子が壁面滑りを抑制する効果について}

各直径の球状粒子を分散させた試料に対して 3.2 節と同様 に応力増加試験を実施した. Fig. 9 に応力増加率 $a=0.05 \mathrm{~Pa} /$ $\mathrm{s}$ におけるひずみ一時間線図を示す。球状粒子を分散させて いない試料をガラス製流路で測定した結果（図中の○記号） は, 応力の増加に伴いひずみが二次関数的に増加している. これに対し，同様の試料を金属製流路で測定した結果（図中 の記号）は，ひずみの増加が一次関数的であることがわか る。これらの結果は，ガラス製流路では壁面滑りが発生する ことで見かけ上粘性係数が低下したことを示唆する. 次に, ガラス製流路で球状粒子を分散させた試料を測定した条件に 注目すると, 球状粒子を分散させていない条件と比較してひ ずみの増加は軽減されていることがわかる，また，試験終了 時における最終到達ひずみ量は金属製流路の結果とほとんど 同じか, それよりも小さい值となっている。 ここで, ガラス 製流路における粒子の分散ありなしのひずみ量の差はおよそ 0.007 となる。これに対し, 定常粘弾性試験における球状粒 子の分散ありなしでの粘度の差は最大で $2200 \mathrm{Pas}$ 程度であ り, 式(3)をもとに $a=0.05 \mathrm{~Pa} / \mathrm{s}$ の応力増加試験のひずみに 換算すると，その差は 0.0015 程度となる。したがって, Fig. 9 の結果は球状粒子が壁面滑りの発生・発達を抑制した ものと考えられる.

Fig. 9 で得られたひずみ挙動に対してマクスウェル近似を 適用し見かけの粘性係数と弾性率を導出した. Fig. 10 にそ れぞれの測定条件における粘性係数および弾性率に対する応 力増加率の依存性を示す. Fig. 10 (a) に示す粘性係数 $\eta$ の結 果では粒子の分散により金属製流路による測定結果とほぼ同 等の值まで $\eta$ が増加している。 また, 応力増加率の増加に対 する $\eta$ の減少率も金属製流路と近い状態となっている。一方, Fig. 10 (b) に示す弾性率 $E$ は粒子分散の影響がほとんどなく, 流路の表面粗さの影響も受けずに安定した結果が得られてい る。このように球状粒子を分散させることで弾性物性值には ほとんど影響を与えることなく，簡便に流路壁面滑りによる

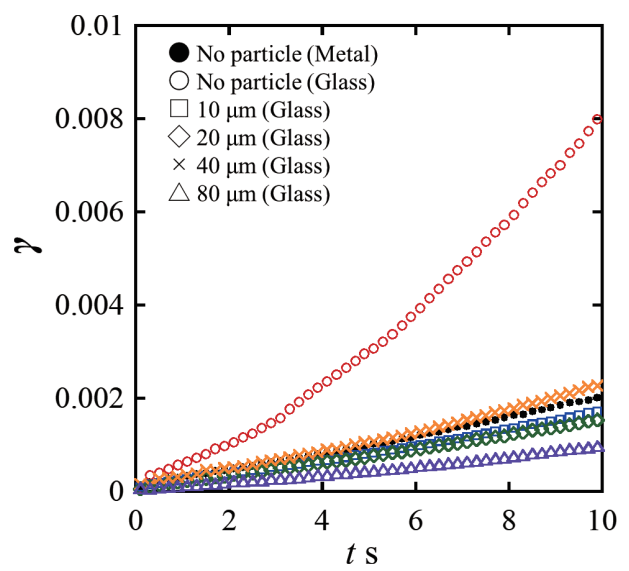

Fig. 9 Strain over test time in $a=0.05 \mathrm{~Pa} / \mathrm{s}$. The strain without the dispersing particles in the glass plate is the biggest in all condition and the ones with the dispersing particles in the glass plate is almost the same as the result of the metal plate.
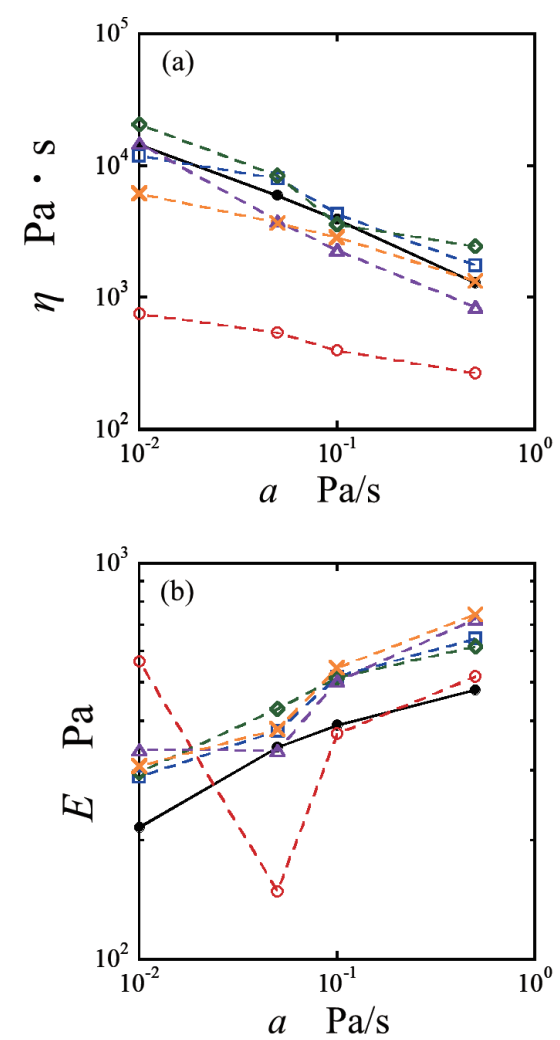

Fig. 10 Stress-ramp rate dependence of viscoelastic property in both plates measuring sample with dispersing particles. (a) viscosity and (b) elasticity. ( ) Metal, $(\bigcirc)$ Glass, $(\square) 10 \mu \mathrm{m}$ in Glass, $(\diamond) 20 \mu \mathrm{m}$ in Glass, $(\times) 40 \mu \mathrm{m}$ in Glass, and $(\triangle) 80 \mu \mathrm{m}$ in Glass. To disperse the sphere particle, the results are close to the metal plate.

粘度の見かけの低下を防ぎ，流路材質によらない安定した結 果が得られることが明らかとなった。

先の結果より球状粒子を分散させることにより，簡便で効 果的に壁面滑りによる見かけの粘度低下を防ぐことが示され た。次に，壁面滑りの抑制に対して分散させる粒子の直径の 効果について調べる. Fig. 11 はマクスウェル近似から算出 された見かけの粘性係数および弾性率に対する分散粒子の直 径依存性を示す。Fig. 11 では球状粒子を分散させていない 条件を $d=0 \mu \mathrm{m}$ と記載している. Fig. 11 (a)の粘性係数の結 果より, 金属製流路では粒子の分散の有無にかかわらず粘度 

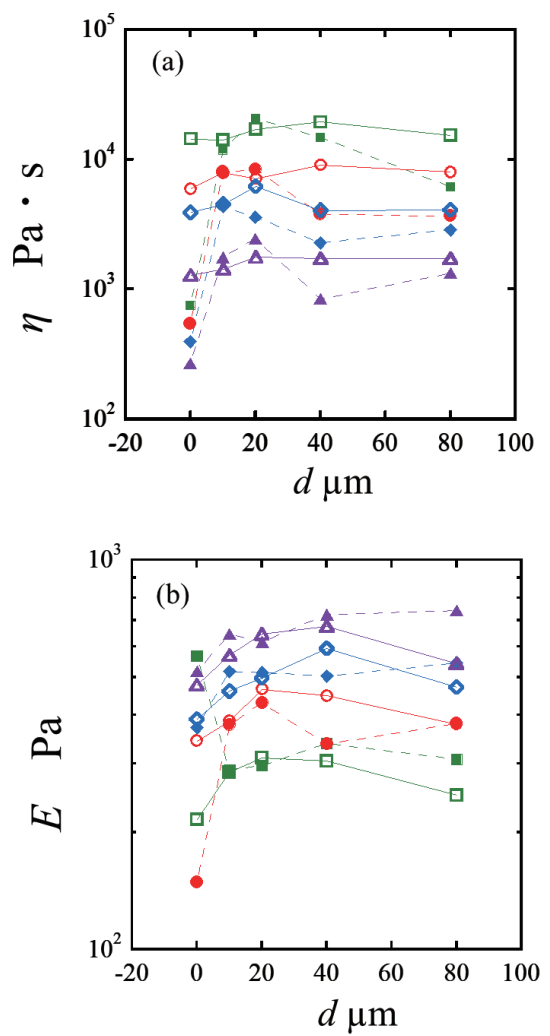

Fig. 11 Suppression effect to the wall-slip in each diameter of dispersing particles. (a) viscosity and (b) elasticity. ( $\square$ ) $a=0.01 \mathrm{~Pa} / \mathrm{s},(\bigcirc)$ $a=0.05 \mathrm{~Pa} / \mathrm{s},(\diamond) a=0.1 \mathrm{~Pa} / \mathrm{s}$ and $(\triangle) a=0.5 \mathrm{~Pa} / \mathrm{s}$. Open symbol corresponds the metal and Filled symbol corresponds the glass. In any dispersing particle size, the viscoelastic property is close to the metal plate's property.

はほとんど変化しないことがわかる，一方，ガラス製流路で は粒子を分散させることで粘度が金属製流路とほとんど同じ 值まで増加する。今回使用した $10 \mu \mathrm{m}$ 以上の粒子では直径 の影響はほとんど現れていない。 また, Fig. 11(b)の弾性率 では流路の状態, 粒子の有無, 直径の大小などほとんど結果 に影響を及ぼさないことがわかる。これらの結果より, 壁面 滑りのせん断層厚さよりも十分に大きい粒子を分散させるこ とで流路の表面粗さによるレオロジー測定の誤差を抑制可能 なことが明らかとなった，壁面滑りの影響を受けない弾性率 において粒子混入の影響が小さいことから, 今回使用した粒 子の大きさ, 濃度は本来の流動場であるクエット流れの速度 分布に影響を及ぼすものではなく, 壁面滑りのみを効果的に 抑制できていると考える。

\section{4. 結 言}

本研究では降伏応力流体のせん断流動において壁面滑りに よりレオメータで計測されるひずみが過大に評価されること を実験的に示した。そして, 壁面滑りを抑制して流路表面粗 さが測定結果に与える影響を小さくする簡便な手法として球 状粒子の分散を提案し，その効果を実証した.

表面粗さが大きく異なる金属製およびガラス製の平行平板 流路を使用し, 壁面滑りの影響が現れやすい応力増加試験を 実施した。使用した試料である $\alpha$ ゲル O/W エマルションに おいて第 1 降伏点以下の微小ひずみ領域で表面粗さの効果が 明確に現れたことから, この領域においてひずみの過渡的挙
動を単一緩和マクスウェルモデルで近似し, 弾性により発生 する回復可能なひずみと粘性によるひずみを求めた。粘性に よるひずみは表面粗さの影響を強く受け, 壁面滑りの発生に より見かけの粘度が $1 / 10$ 以下に低下した。

これに対して壁面滑りによるせん断層厚さよりも遥かに大 きい直径 $10 \mu \mathrm{m}$ 以上の球状粒子を $5 \mathrm{wt} . \%$ 分散させることで, ガラス製流路で生じる壁面滑りを抑制し，金属製とほほ同等 のレオロジー特性が評価可能となることを示した。本手法は 第 1 降伏点以下の領域におけるレオロジー特性を壁面滑りを 抑制して評価したい場合において有効であると考える.

\section{謝 辞}

本研究の一部は,「コロイド溶液の降伏挙動を含む流動特 性の解明」として日本科学協会の笹川科学研究助成から助成 を受けて実施しました。ここに記して謝意を表します。

\section{REFERENCES}

1) Bingham EC, "Fluidity and plasticity", (1922), Mcgraw-Hill Book Company Inc, NY.

2) Coussot P, Rheol Acta, 56, 163 (2017).

3) Homma I, Sato Y, Takahashi T, Noda K, Sogabe A, Nihon Reoroji Gakkaishi (J Soc Rheol Jpn), 46, 2 (2018).

4) Homma I, Takahashi T, Noda K, Sogabe A, Nihon Reoroji Gakkaishi (J Soc Rheol Jpn), 45, 5 (2017).

5) Steven PM, Roger TB, Michel C, J Rheol, 48, 1295 (2004).

6) Steven PM, Roger TB, Michel C, Phys Rev Lett, 92, 198032 (2004).

7) Nabata Y, Proc 56th National Cong Theor Appl Mech, (2014) (in Japanese).

8) Nabata Y, Proc 57th National Cong Theor Appl Mech, (2015) (in Japanese).

9) Nabata Y, “Keshohin no Reoroji”, (2015), Yoneda Publishing, Tokyo (in Japanese).

10) Aral BK, Kalyon DM, J Rheol, 38, 957 (1994).

11) Buscall R, McGowan JI, Mortonjones AJ, J Rheol, 37, 621 (1993).

12) Princen HM, J Colloid Interface Sci, 105, 150 (1985).

13) Russell WB, Grant MC, Colloids Surf A, 161, 271 (2000).

14) Salmon JB, Manneville LBS, Colin A, Eur Phys J E, 10, 209 (2003).

15) Coussot P, J Non-Newton Fluid Mech, 211, 31 (2014).

16) Sato Y, Homma I, Takahashi T, Noda K, Sogabe A, Nihon Reoroji Gakkaishi (J Soc Rheol Jpn), 46, 2 (2018).

17) Watanabe $\mathrm{K}$, Inoue $\mathrm{H}$, Teshigawara $\mathrm{T}$, Kimura $\mathrm{T}$, J Oleo Sci, 61, 29 (2012).

18) Tiu C, Uhlherr PHT, J Ind Eng Chem, 12, 653 (2006).

19) Ann Y, Robert KP, J Rheol, 32, 53 (1988).

20) Thibaut D, David T, Catherine B, Stephen T, Sebastien M, Soft Matter, 8, 4151 (2012).

21) Jose P, Noushine S, Daniel B, Phys Rev Lett, 92, 042316 (2015).

22) Sato Y, Homma I, Takahashi T, J Fluid Sci Tech, 13, 9 (2018).

23) Andreas MVP, Teodor IB, Rheol Acta, 48, 673 (2009). 